\title{
Special issue section of clean technology and environmental policy dedicated to SDEWES 2020 conferences
}

\author{
Tomislav Pukšec ${ }^{1} \cdot$ Neven Duić ${ }^{1}$
}

Published online: 8 February 2022

(c) The Author(s), under exclusive licence to Springer-Verlag GmbH Germany, part of Springer Nature 2022

This special issue (SI) introduction is an overview of papers presented on SDEWES conferences held in 2020, accepted to Clean Technologies and Environmental Policy journal after rigorous review process. It presents a valuable interdisciplinary insight in the topic of sustainable development of energy, water and environment systems. Having said that, there are six research topics covered within this SI; water treatment technologies and procedures, air pollution and forecasts, waste to energy, carbon capture and utilization, urban energy technologies and policies and advances in renewable technology developments, with focus on wind power developments.

In 2020 SDEWES conferences were held in four cities; Buenos Aires (Argentina), Gold Coast (Australia), Sarajevo (Bosnia and Hercegovina) and Cologne (Germany). Altogether Conferences gathered 734 participants from 60 countries and gave opportunity for researchers to gather and exchange ideas and research results in an open and holistic surrounding. In general, SDEWES conferences cover various topics from the economic, engineering, environmental and social studies, to the studies which asses and measure the sustainability of energy, transport, water, environment and food production.
Considering scope and policy of high quality research papers of Clean Technologies and Environmental Policy journal, guest editors have invited 33 research articles, presented on the SDEWES 2020 conferences and after vigorous review process 16 papers have been accepted for publication within this special issue.

From the very beginning, SDEWES conferences focus on holistic approach to sustainability issues research, bringing new knowledge and connect scientists from various research fields. Papers presented and published in special issue journals have been notably cited, which just proves the quality and knowledge that they provide to the scientific community.

The Guest Editors of this SI section have the pleasure of thanking the international team of reviewers who dedicated a great deal of their time and efforts and the Editor-in-Chief of Clean Technologies and Environmental Policy journal, Subhas K. Sikdar for his support and advice.

Publisher's Note Springer Nature remains neutral with regard to jurisdictional claims in published maps and institutional affiliations.

Tomislav Pukšec

Tomislav.Puksec@fsb.hr

1 Department of Energy, Power Engineering and Environment, Faculty of Mechanical Engineering and Naval Architecture, University of Zagreb, Ivana Lučića 5, 10000 Zagreb, Croatia 